Published on Reviews in History (https://reviews.history.ac.uk)

\title{
The Protestant Reformation - a review article
}

Review Number: 2254

Publish date: Thursday, 14 June, 2018

Author: Carlos Eire

ISBN: 9780300111927

Date of Publication: 2016

Price: $£ 22.50$

Pages: 920pp.

Publisher: Yale University Press

Publisher url: http://yalebooks.com/book/9780300111927/reformations

Place of Publication: New Haven, CT

Author: Diarmaid MacCulloch

ISBN: 9780241254004

Date of Publication: 2016

Price: $£ 19.99$

Pages: 464pp.

Publisher: Allen Lane

Publisher url: https://www.penguin.co.uk/books/293492/all-things-made-new/

Place of Publication: London

Editor: Ulinka Rublack

ISBN: 9780199646920

Date of Publication: 2017

Price: $£ 95.00$

Pages: 848pp.

Publisher: Oxford University Press

Publisher url: http://www.oxfordhandbooks.com/view/10.1093/oxfordhb/9780199646920.001.0001/oxfordhb9780199646920

Place of Publication: Oxford

Reviewer: Benjamin M. Guyer

In 2017, many people around the world either celebrated or lamented the 500th anniversary of the Protestant Reformation. According to the standard narrative, on 31 October 1517, a young German monk named Martin Lütter nailed a set of theological theses for debate upon the door of the castle church in Wittenberg. He was upset by the sale of indulgences, which promised the forgiveness of $\sin$ in exchange for a financial donation to the Catholic Church. Lütter saw this as pastorally bankrupt and ethically cruel; he believed that indulgence sellers used the fear of damnation to turn a quick profit for the Church, especially building projects such as St. Peter's in Rome. Following popular convention among humanists, who often wrote under Latin or Greek pseudonyms, Lütter published under the name 'Luther', which he derived from the Greek word for 'freedom', eleutherios. Those who joined Luther initially called themselves 'evangelicals', but in 1530, when they presented to emperor Charles $\mathrm{V}$ a statement of religious principles and convictions known as the Augsburg Confession, they became known as 'Protestants'. However, because Protestants 
agreed more on what they opposed than on what they affirmed, what began as a proposed academic disputation rapidly snowballed into a series of theological and political arguments. Within decades, Western Christendom was divided by incompatibly different religious confessions; in just over a century it was shattered by religiously motivated warfare. This sequence of events was subsequently termed the Reformation, and in later Western historical schemas it became a key episode in modern history. Preceded by the Renaissance and followed by the Enlightenment, the Reformation broke with the Catholic past and helped lay the foundation for a more secular future.

The review essay that follows analyzes three substantive works published to mark the Reformation's fifth centennial. I begin with Ulinka Rublack's edited volume The Oxford Handbook of the Protestant Reformations, continue on with Carlos Eire's tome Reformations, and then engage with Diarmaid MacCulloch's collection of essays All Things Made New. In my conclusion I offer some broad considerations about the state of Reformation scholarship.

I.

The books reviewed here all agree that Martin Luther was the catalyst for the Reformation. There are, however, different ways of framing Luther's import, and this results in divergent ways of framing the Reformation itself. The first approach comes from The Oxford Handbook of the Protestant Reformations; of its 37 essays, only one - Howard Louthan's 'The Bohemian Reformations' - offers sustained analysis of European religious history before Luther. Otherwise, Luther appears unparalleled. In chapter two, Christopher Ocker writes that 'Luther uniquely disrupted traditional practices and beliefs'.(1) Thomas Kaufmann, in a subsection of his essay entitled 'Luther as the starting point of the Reformation', similarly chimes that 'the provocative proposition remains valid: without Luther, no Reformation!'(2) Still later, Michael Hey writes, 'there is no denying that the Reformation began through the initiative of a university professor of theology, Martin Luther'. (3) Finally, the volume concludes with Bruce Gordon: 'With the five hundredth anniversary of Martin Luther's Ninety-Five Theses in 2017 considerable effort has been devoted to assessing the historical significance of both the man and the revolution he began.'(4) The Oxford

Handbook of the Protestant Reformations is undeterred by the very real risk of tedious repetition. Only one essay raises the possibility that this history might be more complex. Andrew Pettegree notes that although Luther was Europe's best-selling author in the early 1520s, 'Luther's writings did not travel particularly well. Ninety per cent of the editions of Luther's works published during the sixteenth century were printed in Germany, and almost 80 percent in German.' (5) This raises the subversive possibility that Luther was far less important for the rest of Europe than the authors cited above claim. But Pettegree's observations are the exception, and this raises a very important question: is The Oxford Handbook of the Protestant Reformations a work of modern historiography, or merely modernized hagiography?

If one wishes to range across the current state of historiography on the Protestant Reformation(s), The Oxford Handbook of the Protestant Reformations is a fine introduction. The volume contains 37 essays organized into six sections. After the first, introductory essay, part one (chapters two to five) studies 'The new theology', part two (chapters six to 17) surveys 'Geographies and varieties of the Reformations', and part three (chapters 18 to 21) investigates 'Communicating the Reformations'. Sections four and five focus on social and cultural history under the headings 'Sites, institutions, and society' (chapters 22 to 27) and 'Identities and cultural meanings of the Reformations' (chapters 28 to 35); the final two chapters are collectively headed 'Assessing the Reformations' and comprise part six. Essay topics are as diverse as 'Political obedience' (chapter five), 'The Reformation of Liturgy' (chapter 20), and 'Natural Philosophy' (chapter 35). In this regard, the fourth and fifth sections are a welcome counterpoint to the second section's lengthy survey of diverse reformations, and the volume's analyses of social history helpfully reveal how distinct religious convictions could affect seemingly innocuous cultural practices, such as music (chapter 30).

Three major editorial decisions are worth noting. First is the plural 'Reformations' in the title of the Handbook. The development of diverse Protestant churches is used to indicate diverse national Reformations rather than a single Reformation. Such plurality stands in curious tension with the volume's consistently star- 
struck vision of Luther, but this is also quite common in current scholarship. Second, the Handbook's date range embraces the 'long Reformation' thesis, which approaches the Reformation(s) as a longue durée. Here there is a problem. Editor Ulinka Rublack claims that the volume ranges 'from ca. 1400 to ca. 1750' (6), but this simply is not true. If it were true, the Handbook would cover far more of 15th-century religion, such as the conciliar councils of Constance (1414-18) and Basel (1431-49). The lack of engagement with conciliarism is especially regrettable, given its pervasive influence upon early Protestants. Third, Rublack describes the volume as 'the most ambitious attempt yet to capture early modern Protestantisms' complex geographies'.(7) But in truth, only two essays attempt a global portrait. The first, Mark Häberlein's 'Protestantism outside Europe' (chapter 17), is very good; it studies Protestant, but primarily English, colonialism. The second global essay is chapter 36 by Merry Wiesner-Hanks, who believes that because Guru Nanak (the founder of Sikhism) and Martin Luther were contemporaries, they are worth reading about together. This is comparative global history at its most clumsy; global approaches shouldn't be forced, and comparison only works if there is a shared ground for comparison (thus apples are usefully compared with oranges because they are both fruit, but it is far more difficult to compare apples with, e.g., Protestants). Chapter 14, 'Protestantism and non-Christian religions', summarizes European Protestant understandings and stereotypes about Judaism and Islam, but the essay is circumscribed by European horizons. Regrettably, the Handbook sometimes oversells itself where it is most underdeveloped.

One major theme is missing from the volume. An essay on confessionalization is necessary for both thematic and methodological reasons. Thematically, the religious fragmentation of Europe occurred because different nations embraced different understandings of Christianity. Without tracing out that history, one risks allowing Whig prejudice do the explanatory work: Protestants believed in freedom, but Catholics believed in authority. Rublack explicitly eschews Whig interpretations in her introduction (8), but the volume itself offers no sustained counter-narrative. Methodologically, the Handbook approaches its subject matter as the work of great men with explosive ideas. The volume's material on social and cultural history is supplementary to this vision - hence the book's largest section is the second, which traces out national Protestant movements. But a second approach is possible, one that involves foregrounding not Luther, but the confessions that circulated from 1530 onward. Confessional documents, not the writings of individual theologians, demarcated distinct geographies no less than distinct theologies. Catechisms, often based upon this confessional material, instantiated distinct religious visions in the household and thus across generational lines. Although confessions were shaped by larger theological debates, they also existed to affirm publicly what a given church believed. They largely avoided theological quiddities in favor of those things considered essential - and on such essential matters, there was oftentimes more common ground between not just Protestant groups, but between Protestants and Catholics as well.

The Oxford Handbook of the Protestant Reformations contains some very good essays. Although uneven, much of it may be read with profit, and it will be a fine addition to academic libraries, especially those concerned with the history of Christianity and/or early modern Europe.

II.

A second, different way of framing Luther may be found in Carlos M. N. Eire's Reformations, although it too emphasizes Luther's import. The preface begins, 'Sometimes, the course of history can change instantly, in the blink of an eye, and everyone notices'. Eire elucidates that

Despite much wrangling, most historians have agreed for five centuries about when and where one such epochal shift took place. The time was late October 1517. The place was the University of Wittenberg in Saxony, a new and undistinguished school. The man involved was an obscure monk named Martin Luther. The event was a simple act of defiance: Luther's public questioning of widely accepted teachings concerning the forgiveness of sins. The era supposedly initiated then and there was called the Reformation. 
But following through on the hesitation evidenced by the last sentence of this quote, Eire seems to back away. He asks, 'Should so much change be ascribed to one person and one event?' He offers a qualified yes. Luther's theses 'set off a chain reaction ... a conflagration of epic proportions' $(9)$, and although it is wrong to say 'that Luther changed his world single-handedly', what followed Luther 'still continues to shape our world today and to define who we are in the West'.(10) Post hoc is not necessarily propter hoc, but it serves to frame and thus draw our attention to the catalytic moment. Eire thus discusses far more of the 15th century than the Handbook does. This, then, is the second way of framing Luther: relating enough of 15thcentury history to place Luther into some sort of historical context that nonetheless serves to highlight his remarkable distinctiveness.

Eire organizes his volume into four sections. Part one, 'On the edge', contains six chapters and begins in 1450 with the construction of St. Peter's in Rome. The last chapter of part one studies 'Forerunners of the Catholic Reformation'; Protestants later lionized some of these figures, such as Savonarola, while others, such as St. Catherine of Genoa, became paragons of Roman Catholic sanctity. On the penultimate page of this chapter, Eire asks whether these forerunners 'prove that the Catholic Church was beginning to reform itself before all hell broke loose in 1517?'(11) He answers in the negative, and his question sets up Luther as a historical pivot. Part two, 'Protestants', begins in 1510, when Martin Luther first arrived in Rome, and where he himself participated in the buying of indulgences - a practice that, as noted, he later rejected. This section has seven chapters; the first three detail Luther, while the other four successively analyze the Swiss Reformation, the Radical Reformation, Calvin and Calvinism, and finally the churches in the British Isles. Part three, 'Catholics', begins in 1564 and again in Rome, with the construction of four pillars of St. Peter's dome. The narrative that rounded out part one is picked back up in this section; the six chapters of part three focus on Catholic Reform (four chapters) before turning to Catholic missionary work (two chapters). Part four, 'Consequences', surveys the 17th century; these seven chapters open in 1626 with the consecration of St. Peter's and conclude in the middle of the 18th century with a resolutely skeptical enlightenment in full swing. Here are sustained discussions of topics as diverse as religious war, confessionalization, popular demonology, and elitist skepticism.

Despite Luther's central import, as the above makes clear, Eire positions the slow building of St. Peter's as a thread of continuity that extends from the beginning through the end of his narrative. There is a significant advantage in constructing his account this way, for it raises the possibility that the changes covered in Reformations could just as easily be read against the background of a longue durée. I am willing to question whether Europe really orbited around the theological arguments that emanated from Wittenberg, but few if any would debate whether there were points of continuity wholly independent of the purported fulcrum of 31 October 1517. Eire's repeated discussions of St. Peter's stand in irresolvable tension with his emphasis upon Luther, and he does not attempt to resolve the discrepancy between these. At the beginning of part four, Eire writes, 'The consequences of what began to unfold in 1517 can be felt but not yet fully fathomed in 1626.' (12) Thus Luther contextualizes St. Peter's. But one could just as easily argue that St. Peter's ought to contextualize Luther - and if we consider this, we might further consider that the longue durée which began in the 15th century also continued on through the 17th. At a pedagogical level, there is considerable value in Eire's use of a single architectural marvel as a site for thinking about continuity. When I teach Reformation Europe next spring, I will follow suit by introducing such an element into my course, possibly St. Peter's itself. No one has yet figured out how to balance continuity with change in the study of history, much less in the study of Reformation Europe, but Eire offers a compelling model for how this might be done constructively.

A great strength of Reformations is its integration of Protestant with Catholic history. The roughly 150 pages of part three could easily be treated as a survey of 16th-century Catholicism. Chapters 18 and 19 look at Catholic missions, and when compared with the chapters on point in The Oxford Handbook of the Protestant Reformations, it is more than evident that early modern Catholics had both a missionary vision and a missionary zeal. Eire utilizes choice illustrations throughout, but several of the pictures found in these chapters are especially vivid, such as a Mesoamerican illustration of human sacrifice (13), and a page from 
the Illustrated Life of Our Lord Jesus Christ, a Jesuit work published for Chinese inquirers and converts.(14) If the illustrated contents of Reformation are treated as representative, then Protestant devotional artwork was in far shorter supply than that among Catholics. There are some exceptions, but the Protestant religious art appears more consistently polemical, even though some remarkable examples of Protestant - specifically Lutheran - devotion can be seen, such as Lucas Cranach the Younger's 1555 altarpiece in the church of SS. Peter and Paul.(15) The artwork, ranging from simple woodcuts to high Renaissance masterpieces, is worth studying.

Reformations is a massive study of early modern Europe, both Protestant and Catholic. It is a volume worth perusing carefully, both to think with and to learn from.

III.

Diarmaid MacCulloch's volume is a very different sort of work. When Herbert Butterfield wrote The Whig Interpretation of History in 1931, he hoped to separate historical research from moral declamation. In his opening sentence, Butterfield pointed to the problem. 'It has been said that the historian is the avenger, and that standing as a judge between the parties and rivalries and causes of bygone generations he can lift up the fallen and beat down the proud, and by his exposures and his verdicts, his satire and his moral indignation, can punish unrighteousness, avenge the injured or reward the innocent.' $\underline{(16)}$ Butterfield observed that confusing moral with historical discourses resulted in historians failing to explicate the past on its own terms. In his final chapter, 'Moral judgments in History', Butterfield explained, 'If he [the historian] deals in moral judgments at all he is trying to take upon himself a new dimension, and he is leaving that realm of historical explanation, which is the only one he can call his own.' (17) Historical work involves sifting sources, following the evidence where it leads, and controlling one's passions in the process. Historical research is empirical research. When it is not, it is simply not historical.

In All Things Made New: The Reformation and its Legacy, MacCulloch rejects Butterfield's vision. Near the end of his Preface, MacCulloch writes, 'These essays reflect my belief that the proper study of history has a purpose, indeed (to be portentous), a moral purpose: it forms a powerful barrier against societies and institutions collectively going insane as a result of telling themselves badly skewed stories about the past'. (18) In and of itself, such a comment need not occasion further discussion; would any historian really deny that historical research has a corrective function? But as the book progresses, it becomes clear that MacCulloch has indeed assumed the role of moral arbiter. All Things Made New contains both popular and academic essays. In his popular pieces, MacCulloch hits out at religious conservatives; in his academic articles, he targets Anglo-Catholics. He alleges that 'Those who call themselves religious traditionalists tend to be those who do not know enough about their religious tradition, or who have edited out those parts which they do not like. Moreover, their proclaimed traditionalism too often turns out to be a tradition of saying no rather than yes.'(19) Such personal sentiments raise pointed questions about some of MacCulloch's professional judgments. In an essay on Henry VIII, he writes, 'Conservatives may not have known much about theology, but they knew what they disliked.' (20) Is such a claim about 16th-century history or something else? MacCulloch has previously discussed his homosexuality and the profound strain that it placed upon his relationship with the Church of England. It is therefore worth considering that, despite its title, All Things Made New is a partial revival of confessional historiography. The difference here is that unlike the old confessional historiography, which used history to justify the stance of an author's particular church, MacCulloch uses history to argue against the conclusions of his own church (in this case, the Church of England's refusal to ordain non-celibate homosexuals). Perhaps we might describe such academicallyinflected partisanship with a neologism: intra-confessional historiography.

Some of the essays reprinted in All Things Made New have had considerable influence upon contemporary scholarship on the English Reformation. Key selections reprinted here include 'The Virgin Mary and the Protestant Reformers' (chapter three) and MacCulloch's 2004 Prothero Lecture, 'Putting the English Reformation on the map'. Chapters 18 to 21 are all substantive engagements with a range of historiographical matters pertaining to the English Reformation. MacCulloch's oft-cited 1991 study 'The 
Myth of the English Reformation' is regrettably missing, but he notes that 'the ideas in it inform much later writing'.(21) All of the book's academic chapters attempt to work out, in diverse ways, the thesis that MacCulloch advanced in that article: 'The myth of the English Reformation is that it did not happen, or that it happened by accident rather than design, or that it was half-hearted and sought a middle way between Catholicism and Protestantism; the point at issue is the identity of the Church of England.' (22) MacCulloch there argued that two groups, the 'Laudians' of the 17th century and the 'Anglo-Catholics' of the 19th, had together conspired 'to emphasize the Catholic continuity of the church over the break of the Reformation'. (23) MacCulloch proposed that this not only distorted Anglican historical self-understanding, but also contained implications for Anglicanism today. Historical analysis thus yielded to a distinctly theological judgment: 'Quite apart from the desirability of getting the facts right, one's understanding of the English Reformation should determine the theological conclusions drawn about the nature of Anglicanism; it should materially influence the decisions that Anglicanism makes about such important internal matters as moving toward the ordination of women and priorities in ecumenical ventures with other churches of the Christian West.' (24) Anglo-Catholics, judged guilty of corrupting Anglican historiography, were thus guilty of corrupting Anglicanism in other ways as well.

But we should also ask: when MacCulloch attacks Anglo-Catholics, is he playing an exclusively academic role? The answer is no; the 'traditionalists' lampooned in his popular essays are identical with the AngloCatholics attacked in his (allegedly?) academic essays. In fact, MacCulloch connected these together in 'The myth of the English Reformation', where he identified Anglo-Catholics as religious conservatives who opposed the ordination of women.(25) 'The myth of the English Reformation' was a sweeping criticism of Anglo-Catholicism and its historians, and yet - curiously - MacCulloch did not cite a single Anglo-Catholic historian in that article. He instead cited the theologians John Henry Newman and Charles Gore. All Things Made New continues in this same vein. The first endnote to 'Putting the English Reformation on the map' contains the assertion that 'One can sample mature Anglo-Catholic distortions and obfuscations throughout the entries relating to the English Reformation in the first edition of an otherwise excellent reference work, The Oxford Dictionary of the Christian Church'.(26) MacCulloch names the offending entries not here but later, in chapter 18. Apparently there are three: the entries on Robert Browne, the Real Presence, and John Stubbs.(27) A genuinely historical argument cannot simply confront and condemn; it must show how these entries departed from the historiographical consensus of their own time (1957, in the case of the first edition of the ODCC). This is called context. Without it, one might as well write history with a hammer.

I am not the first to query MacCulloch's portrayal of Anglo-Catholic historiography.(28) As Peter Nockles has observed, Anglo-Catholic historical writing 'could be nuanced, sophisticated and complex.' (29) Nockles further proposes that 'It was the traditional High Churchmen ... not the Tractarians, who can best be claimed as adherents of the 'Myth of the English Reformation'.'(30) Such critiques should not be ignored. With its pervasively prescriptive content, All Things Made New is less a work of contemporary historical scholarship than a regrettable throwback to an older era of distinctly confessional historiography. There is nothing wrong with having theological convictions but historical scholarship should proceed according to the norms of the historical profession.

\section{Conclusion}

All of the above indicates some dissatisfaction with the contemporary historiography of Reformation Europe. How might it be improved? For starters, it remains unclear why we call this era the Reformation. Such an assertion might puzzle some people, but allow me to explain. Neither Luther nor other Protestants positioned 'reformation' as the conceptual cornerstone for their respective ecclesial and political projects. Protestants authored no manifestoes of reformation; 'reformation' was not a keyword in their writings. By Luther's time, 'reformation' had been a public topic for more than a century, because the councils of Constance, Basel, Lateran V (1512-17), and Trent (1545-63) all used 'reformation' explicitly and extensively in their proceedings. Constance called for 'reformatio in capite in membris' (reformation in head and members); Basel and Lateran V retained this language, and Trent called for the 'reformatio' of numerous abuses. Because the discourse of 'reformation' was far older than Luther, histories of 
'Reformation Europe' should begin where this same discourse began: with the conciliar councils of the 15th century. Consequently, Martin Luther should never be treated as the axis around which Reformation history turns. Does it not make far more sense to see the schisms that came after Luther in the context of the schisms that happened in the century before him? Does it not make far more sense to read the Augsburg Confession in the context of the 15th-century conciliar literature that it so freely cited? These questions need not be rhetorical, and for historians or early modern Europe, they should not be.

I fear that the secular historiography of the Reformation has retained the diachronic organizational markers of confessional hagiography while rejecting only the explicitly apologetic aims of the latter. In Rublack and Eire, we see that Reformation scholarship remains as Luther-centric as any number of writings by later Protestant apologists; even if scholars today make no claim about Luther's place in providential history, his place in European history still appears unprecedented. The resolution to this problem is not a retreat into intra-confessional historiography, but a willingness to rethink the entire interpretive framework that we have received and which we retain. Centenaries should be used for something more than the restatement of old, if endearing, mythologies.

\section{Notes}

1. Christopher Ocker, 'Explaining evil and grace', in The Oxford Handbook of the Protestant Reformations, ed. Rublack, pp. 23-46, at p. 23. Back to (1)

2. Thomas Kaufmann, 'Luther and Lutheranism', in idem., pp. 146-66, at p. 149.Back to (2)

3. Michael Heyd, 'University scholars of the Reformation', in idem., pp. 459-82, at 459.Back to (3)

4. Bruce Gordon, 'History and memory', in idem., pp. 765-86, at 765.Back to (4)

5. Andrew Pettegree, 'Print workshops and markets', in idem., pp. 375-89, at p. 383. Back to (5)

6. Ulinka Rublack 'Introduction', in idem., pp. 1-19, at p. 7.Back to (6)

7. Ibid., p. 5.Back to (7)

8. Ibid., p. 3.Back to (8)

9. Eire, Reformations: The Early Modern World, 1450-1650, p. vii.Back to (9)

10. Ibid., pp. vii-viii.Back to (10)

11. Ibid., p. 128. Back to (11)

12. Ibid., p. 523.

13. Ibid., p. 477. Back to (13)

14. Ibid., p. 511. Back to (14)

15. Ibid., p. 722.Back to (15)

16. Herbert Butterfield, The Whig Interpretation of History (New York, NY, and London, 1965), p. 1. Back to (16)

17. Ibid., p. 130.Back to (17)

18. MacCulloch, All Things Made New, p. xii.Back to (18)

19. Ibid., p. 12.Back to (19)

20. Ibid., p. 108.Back to (20)

21. Ibid., p. xi.Back to (21)

22. Diarmaid MacCulloch, 'The myth of the English Reformation', Journal of British Studies, 30, 1 (January 1991), 1-19, 1.Back to (22)

23. MacCulloch, 'The myth of the English Reformation', p. 1.Back to (23)

24. MacCulloch, 'The myth of the English Reformation', p. 2; emphases mine.Back to (24)

25. Ibid. This was unfair at the time; since the late 19th century, Anglo-Catholicism has covered a range of theological convictions, ranging from the more traditional to the more liberal.Back to (25)

26. MacCulloch, All Things Made New, p. 389, n. 1.Back to (26)

27. Ibid., p. 401 n. 6.Back to (27)

28. Alexander Faludy, 'A son of the Reformation? Walter Frere's historical scholarship reviewed', in Walter Frere: Scholar, Monk, Bishop, ed. Benjamin Gordon-Taylor \& Nicholas Stebbing (Norwich, 2011), 119-42; Peter Nockles, 'The Reformation revised? The contested reception of the English Reformation in nineteenth-century Protestantism', Bulletin of the John Rylands Library, 90, 1 (Spring 
2014), 231-56.Back to (28)

29. Nockles, 'The Reformation revised?', p. 241.Back to (29)

30. Nockles, 'The Reformation revised?', p. 242.Back to (30)

\section{Other reviews:}

Literary Review

https://literaryreview.co.uk/across-the-great-divide [4]

New York Times

https://www.nytimes.com/2016/08/14/books/review/reformations-carlos-m-n-eire.html [5]

Irish Times

https://www.irishtimes.com/culture/books/all-things-made-new-writings-on-the-reformation-by-diarmaid-

macculloch-1.2731267 [6]

Washington Independent Review of Books

http://www.washingtonindependentreviewofbooks.com/index.php/bookreview/all-things-made-new-the-

reformation-and-its-legacy [7]

Financial Times

https://www.ft.com/content/d6cdfc92-44f4-11e6-b22f-79eb4891c97d [8]

Catholic Herald

http://catholicherald.co.uk/issues/july-15th-2016/a-witty-but-alarming-take-on-the-reformation/ [9]

Source URL:https://reviews.history.ac.uk/review/2254

\section{Links}

[1] https://reviews.history.ac.uk/item/198083 [2] https://reviews.history.ac.uk/item/246987

[3] https://reviews.history.ac.uk/item/298810 [4] https://literaryreview.co.uk/across-the-great-divide

[5] https://www.nytimes.com/2016/08/14/books/review/reformations-carlos-m-n-eire.html

[6] https://www.irishtimes.com/culture/books/all-things-made-new-writings-on-the-reformation-by-diarmaidmacculloch-1.2731267 [7]

http://www.washingtonindependentreviewofbooks.com/index.php/bookreview/all-things-made-new-thereformation-and-its-legacy [8] https://www.ft.com/content/d6cdfc92-44f4-11e6-b22f-79eb4891c97d

[9] http://catholicherald.co.uk/issues/july-15th-2016/a-witty-but-alarming-take-on-the-reformation/ 